\title{
USING DRIED LEFTOVER FOODS AS UNTRADITIONAL FEED IN MUSCOVY DUCK DIETS
}

\author{
ENASA F. MOUSA ${ }^{1}$; HASSAN A.M. ABDEL-RAHEEM ${ }^{2}$ and GEHAN R.M. DAWOOD ${ }^{3}$ \\ ${ }^{1}$ Animal and Clinical Nutrition Dept., Fac. of Vet. Med., South Valley University, Qena, Egypt \\ ${ }^{2}$ Animal and Clinical Nutrition Dept., Fac. of Vet. Med., Assiut University, Assiut, Egypt \\ ${ }^{3}$ Food Hygiene Dept. Fac. of Vet. Med., South Valley University, Qena, Egypt
}

Received: 28 June 2018; Accepted: 30 July 2018

\begin{abstract}
The current work was conducted to investigate the effect of dietary leftover food inclusion on growth performance, carcass traits and some blood biochemical parameters of Muscovy ducks. Thirty six (36) two-week old ducks (average weight $393.2 \mathrm{~g}$ ) were obtained from local commercial source and randomly distributed into 4 groups (9ducks/each). In the first group, ducklings were fed ad-libitum on grower-finisher control diet (diet 1), while birds in the second, third and fourth groups fed on diets containing 10\%, $20 \%$ and $30 \%$ leftover food, respectively (diets $2,3,4)$. The experimental diets were formulated in a mash form (yellow corn, soybean meal, wheat bran and sunflower oil) to meet the minimum nutrient requirements cited by NRC (1994) for ducks. Ducklings were fed according to one phase feeding program (grower- finisher, 14- 70 days). Growth performance, carcass traits and some blood biochemical parameters were assessed. The results showed that, ducks fed on diets containing 10, 20,30\% leftover food achieved significantly $(\mathrm{p}<0.05)$ higher body weight gain $(3084.2 \pm 30.3,3141.5 \pm 30.8,3169.0 \pm 29.1 \mathrm{~g})$, respectively compared with the control $(2945.2 \pm 22.3 \mathrm{~g})$ with lower feed intake. Highest weight gain averages with best feed conversion (3.22, 3.14, and 3.11) respectively compared with the control. The highest dressing percentage was recorded in ducks fed on diet containing $30 \%$ leftover food $(79.3 \%$ ), while the lowest was observed in control group (75.6\%). Addition of leftover food to duck diets had no significant effect $(\mathrm{p}<0.05)$ on the weights of internal organ. Total serum protein, albumin and globulin values were decreased significantly $(\mathrm{p}<0.05)$ by increasing the level of dietary leftover food. Inclusion of leftover food to duck diets increase significantly $(\mathrm{p}<0.05)$ triglycerides and had no significant effect on serum cholesterol. Results of the current study concluded that, the best growth performance and economical feed efficiency was observed in ducks fed on diet containing 30\% leftover food which surpassing all treated groups and achieved the best body weight gain.
\end{abstract}

Key words: Growth performance, carcass traits, leftover food, ducks

\section{INTRODUCTION}

Poultry industry is one of the most dynamic agribusiness trades worldwide. The importance of feed supplementation in poultry production has increased in the last years with the aim of improving the economic situation of poultry projects. Therefore, it is highly essential to improve feed efficiency of poultry to produce meat economically and also food safety is more seriously considered than before. On the other hand, economy of food production is also a factor that cannot be ignored. Livestock production in many developing countries is constrained because of poor nutrition, short supply of animal feeds and poor

Corresponding author: Dr. ENASA. F. MOUSA

E-mail address: drenas_86@yahoo.com

Present address: Animal and Clinical Nutrition Dept., Fac. of Vet. Med., South Valley University, Qena, Egypt quality of available feeds (International Atomic Energy Agency, IAEA 2011). Furthermore, it was recognized that utilization of alternative feedstuffs may play a crucial role in livestock production; especially as substitute for the traditional feedstuffs that are not readily available or are expensive. For a sustainable development of the livestock sector, it is essential to secure sufficient supply of balanced feed from resources that have no use in human nutrition. Leftover food is defined as any edible waste from food production, transportation, distribution and consumption; it is also referred as garbage, swill, and / or kitchen waste (Kornegay et al., 1965 and Price et al., 1985). Feedstuffs such as kitchen leftovers can be used in Egypt, and could be invaluable feed resources for small and medium size holders of livestock. Food leftover (food wastes) are not fully utilized and substantial amounts of nutrients lost during preparation of food, especially from cafeterias of universities, hospitals and hotels. Currently, large amounts of food waste generated from household and 
industries have become one of the main factors to cause environmental pollution. To overcome this problem the change of food leftover to useful materials is the best option. The best recycling way of food waste to minimize the pollution is converting it to animal feed (Kim et al., 2001). Therefore, dried leftover could be used as a supplemental feed or a feed ingredient for swine and poultry (Kim et al., 1995) not only to decrease the use of expensive feed ingredients, such as imported feeds, but also to reduce environmental pollution (Yang et al., 2001). This study was conducted to estimate the nutritive value of leftover food and the effects of its inclusion to duck diets on growth performance, carcass traits and some blood biochemical parameters.

\section{MATERIALS AND METHODS}

The current work was carried out at the Veterinary research farm, Department of Animal Nutrition and Clinical Nutrition, Faculty of Veterinary Medicine, South Valley University (March- May 2017).

\section{Experimental ducks and housing:}

Thirty six Muscovy ducks (two weeks old) with average weight of $393.2 \pm 18.5 \mathrm{~g}$ were randomly distributed into 4 groups, each of 9 ducks. Ducks were housed in floor pens and kept under the same managerial system and environmental conditions. A cycle of 16 hours light and 8 hours dark were applied throughout the experiment and hygienic disposal of organic washes were followed. For controlling diseases and increase viability, ducks were subjected to a prophylactic and pharmacological program against viral and bacterial diseases.

\section{Diets and feeding:}

The standard control diet (diet 1) was formulated in a mash form (yellow corn, soybean meal, wheat bran and sunflower oil) to meet the minimum nutrient requirements cited by NRC (1994) for ducks. Three experimental diets were formulated to contain 10, 20 and $30 \%$ leftover food (diets 2, 3, 4). In the first group, ducklings were fed ad-libitum on growerfinisher standard control diet (diet 1). This group assigned as a control which the other groups were compared. Ducklings in the second, third and fourth groups were fed ad-libitum on grower-finisher diets containing $10 \%, 20 \%$ and $30 \%$ leftover food, respectively. Ducklings were fed according to one phase feeding program (grower- finisher, 14- 70 days). Ducks were fed ad-libitum on the respective diets in mash form and given free access to fresh water throughout the experimental period. The physical and chemical composition and energy values of the feed ingredients and experimental diets are presented in Table $(1 \& 2)$.

Table 1: Chemical composition and metabolizable energy values of the ingredients.

\begin{tabular}{|c|c|c|c|c|c|c|c|}
\hline \multirow{3}{*}{ Ingredients } & \multicolumn{6}{|c|}{ Chemical composition (\%) } & \multirow{3}{*}{ ME (kcal/kg)* } \\
\hline & \multicolumn{6}{|c|}{ (As fed basis) } & \\
\hline & DM & $\mathbf{C P}$ & $\mathbf{E E}$ & CF & NFE & ASH & \\
\hline Yellow corn, ground & 88.50 & 9.50 & 3.70 & 2.11 & 70.97 & 2.22 & 3350 \\
\hline Soybean meal & 91.12 & 45.00 & 1.90 & 6.55 & 32.36 & 5.31 & 2230 \\
\hline Wheat bran & 91.00 & 14.51 & 4.45 & 11.00 & 55.36 & 5.68 & 1300 \\
\hline Sunflower oil & 99.00 & --- & 99.00 & --- & --- & --- & 8600 \\
\hline Leftover food & 55.60 & 17.40 & 14.50 & 5.00 & 10.50 & 8.20 & 3380 \\
\hline
\end{tabular}

* ME $=$ Metabolizable energy cited by NRC (1994)

Collection \& Processing of leftover food:

Leftover food was collected from Quick door restaurant and Dream Hotel by veterinary farm workers. Leftover food was minced then heated and dried in hot air oven at $85^{\circ} \mathrm{C}$ for 4 hours at Animal \& Clinical Nutrition lab., Fac. Vet. Med., South Valley University. Chemical composition of leftover food including $\mathrm{DM}, \mathrm{CP}, \mathrm{EE}, \mathrm{CF}$, ash and $\mathrm{NFE}$ was estimated according to the methods of Association of Official Analytical Chemists (AOAC, 1990). Energy value of leftover food was measured by bomb calorimeter at Animal \& Clinical Nutrition lab, Fac. Vet. Med, Assuit University. 
Table 2: Composition and energy values of the experimental diets.

\begin{tabular}{|c|c|c|c|c|}
\hline Items & 1 & 2 & 3 & 4 \\
\hline \multicolumn{5}{|l|}{ Physical composition $(\%)$} \\
\hline Yellow corn, ground & 64.60 & 52.00 & 49.00 & 43.40 \\
\hline Soybean meal & 18.80 & 16.00 & 13.70 & 11.00 \\
\hline Wheat bran & 10.00 & 15.00 & 12.00 & 12.10 \\
\hline Sunflower oil & 3.40 & 4.30 & 2.60 & 1.50 \\
\hline Leftover food & --- & 10.00 & 20.00 & 30.00 \\
\hline Mono sodium phosphate & 0.9 & 0.6 & 0.6 & 0.4 \\
\hline Limestone, ground & 1.50 & 1.20 & 1.20 & 0.70 \\
\hline Common salt & 0.30 & 0.30 & 0.30 & 0.30 \\
\hline Methionine & 0.20 & 0.30 & 0.30 & 0.30 \\
\hline Premix* & 0.30 & 0.30 & 0.30 & 0.30 \\
\hline \multicolumn{5}{|l|}{ Chemical composition $\%$} \\
\hline Dry matter & 86.76 & 84.05 & 74.89 & 77.59 \\
\hline Crude protein & 16.00 & 16.00 & 16.00 & 16.00 \\
\hline Ether extract & 6.54 & 7.13 & 6.62 & 8.16 \\
\hline Crude fiber & 3.69 & 4.28 & 4.24 & 5.42 \\
\hline Nitrogen-free extract & 57.45 & 44.77 & 47.94 & 44.19 \\
\hline Ash & 2.98 & 3.66 & 4.12 & 4.68 \\
\hline Calcium & 0.60 & 0.60 & 0.60 & 0.60 \\
\hline Phosphorus, available & 0.30 & 0.30 & 0.30 & 0.30 \\
\hline Lysine & 0.66 & 0.65 & 0.67 & 0.66 \\
\hline Methionine & 0.40 & 0.50 & 0.50 & 0.50 \\
\hline $\mathrm{ME}(\mathrm{Kcal} / \mathrm{kg})$ & 3005 & 3001 & 3002 & 2999 \\
\hline
\end{tabular}

*Each 3 kg contains: Vit. A, 1200000 IU; Vit. D 3 , 300000 IU; Vit. E, 700 mg; Vit. k3, 500 mg; Vit. B 1,500 mg; Vit. B2, $200 \mathrm{mg}$; Vit. B $600 \mathrm{mg}$; Vit. B $12,3 \mathrm{mg}$; Vit. C, $450 \mathrm{mg}$; Niacin, $3000 \mathrm{mg}$; Methionine, $3000 \mathrm{mg}$; Pantothenicacid, $670 \mathrm{mg}$; Folicacid $300 \mathrm{mg}$; Biotin, $6 \mathrm{mg}$; Choline chloride, $10000 \mathrm{mg}$; Magnesiumsulphate, 3000 mg; Copper sulphate, 3000 mg; Ironsulphate, 10000 mg; Zinc sulphate, $1800 \mathrm{mg}$; Cobalt sulphate, 300 $\mathrm{mg}$.

\section{Growth performance parameters:}

Live body weight of ducklings was individually recorded at the beginning of experiment and then weekly throughout the 8 weeks of the experimental period. Individual LBW was totalized and divided by the number of ducks to obtain the average LBW. Body weight gain of ducklings for each week was calculated by subtracting the LBW at the beginning of each week from that at the end of the same week. The amount of feed intake was weekly recorded in each of the different experimental groups. Average amount consumed by each bird was calculated by dividing the weekly consumed food by its respective number of birds in each group at this week. FCR was calculated weekly as $\mathrm{kg}$ feed intake / $\mathrm{kg}$ gain of body weight.

\section{Carcass traits:}

At the end of the experiment, three birds from each group were slaughtered after fasting overnight, processed and the weight of dressed carcass (the weight of slaughtered birds after removal of feathers, head and feet but including all the edible offal's), liver, spleen, gizzard and heart were recorded the organ weights were expressed as relative weight to pre-slaughter weight.

\section{Blood samples:}

Blood samples were collected from the three slaughtered birds in non-heparinized tubes. Serum was separated by centrifugation at $3000 \mathrm{rpm}$ for 10 minutes and stored at $-18^{\circ} \mathrm{C}$ till further analysis. Total serum protein, albumin, globulin, total cholesterol and triglycerides were determined using standard kits supplied by Bio-Merieux (Baines/France).

\section{Economical evaluation:}

Total feed cost, total production cost, price of body weight, net revenue and economical feed efficiency were calculated.

\section{Statistical analysis:}

Statistical analysis of the obtained raw data was carried out according to procedures of completely random design SAS (1995). 


\section{RESULTS}

Weekly body weight development of ducks fed diets containing different levels of leftover food are presented in Tables 3. The performance measurements of ducks including body weight gain, feed consumption, feed conversion ratio (weekly and during whole experimental period) are shown in Tables 4,5 \& 6.

Table 3: Body weight development (g) of ducks fed the different experimental dietshc.

\begin{tabular}{ccccc}
\hline Age/group & 1 & 2 & 3 & 4 \\
\hline 2 weeks & $395.3 \pm 19.7^{\mathrm{a}}$ & $416.0 \pm 18.3^{\mathrm{a}}$ & $391.5 \pm 178^{\mathrm{ab}}$ & $370.1 \pm 16.2^{\mathrm{b}}$ \\
\hline 3 weeks & $852.5 \pm 23.8^{\mathrm{ab}}$ & $803.8 \pm 27^{\mathrm{ab}}$ & $736.3 \pm 20^{\mathrm{b}}$ & $902.5 \pm 20.6^{\mathrm{a}}$ \\
\hline 4 weeks & $1273 \pm 39.3^{\mathrm{ab}}$ & $1236 \pm 25^{\mathrm{ab}}$ & $1163 \pm 38.1^{\mathrm{b}}$ & $1298 \pm 36.3^{\mathrm{a}}$ \\
\hline 5 weeks & $1615 \pm 38.3^{\mathrm{ab}}$ & $1633 \pm 32.7^{\mathrm{ab}}$ & $1509 \pm 50^{\mathrm{b}}$ & $1653 \pm 32.7^{\mathrm{a}}$ \\
\hline 6 weeks & $2014 \pm 74^{\mathrm{a}}$ & $2129 \pm 30.5^{\mathrm{a}}$ & $1964 \pm 41.8^{\mathrm{b}}$ & $2121 \pm 55.5^{\mathrm{a}}$ \\
\hline 7 weeks & $2419 \pm 61.2^{\mathrm{b}}$ & $2600 \pm 42.3^{\mathrm{a}}$ & $2525 \pm 49.1^{\mathrm{ab}}$ & $2638 \pm 56.5^{\mathrm{a}}$ \\
\hline 8 weeks & $2769 \pm 54.2^{\mathrm{b}}$ & $2969 \pm 31.2^{\mathrm{a}}$ & $2935 \pm 54.3^{\mathrm{a}}$ & $2902 \pm 65.7^{\mathrm{a}}$ \\
\hline 9 weeks & $3050 \pm 45.3^{\mathrm{b}}$ & $3250 \pm 26.7^{\mathrm{a}}$ & $3224 \pm 62^{\mathrm{a}}$ & $3258 \pm 53^{\mathrm{a}}$ \\
\hline 10 weeks & $3340 \pm 40.8^{\mathrm{b}}$ & $3500 \pm 37.8^{\mathrm{a}}$ & $3533 \pm 45.8^{\mathrm{a}}$ & $3539 \pm 52.3^{\mathrm{a}}$ \\
\hline
\end{tabular}

a Significant difference when compared with control when $(\mathrm{P}<0.05)$

bignificant difference when compared with other treated groups when $(\mathrm{P}<0.05)$

Table 4: Body weight gain (g) of ducks fed the different experimental diets.

\begin{tabular}{ccccc}
\hline Age/group & 1 & 2 & 3 & 4 \\
\hline $2-3$ wks & $451.3 \pm 18.7^{\mathrm{a}}$ & $396.8 \pm 11.7^{\mathrm{ab}}$ & $350 \pm 10.5^{\mathrm{b}}$ & $478.8 \pm 20^{\mathrm{a}}$ \\
\hline $3-4 \mathrm{wks}$ & $420 \pm 19^{\mathrm{a}}$ & $432.5 \pm 12^{\mathrm{a}}$ & $426.3 \pm 24.3 \mathrm{a}$ & $395.0 \pm 28^{\mathrm{b}}$ \\
\hline $4-5 \mathrm{wks}$ & $342.5 \pm 24.6$ & $396.3 \pm 19.3$ & $346.3 \pm 27.1$ & $355 \pm 17$ \\
\hline $5-6 \mathrm{wks}$ & $390 \pm 39.6 \mathrm{a}^{\mathrm{b}}$ & $480 \pm 37^{\mathrm{a}}$ & $472.5 \pm 29.3 \mathrm{a}$ & $491.3 \pm 34.3^{\mathrm{a}}$ \\
\hline $6-7 \mathrm{wks}$ & $418.8 \pm 32.8^{\mathrm{b}}$ & $487.5 \pm 31^{\mathrm{ab}}$ & $543.8 \pm 22^{\mathrm{a}}$ & $493.8 \pm 24^{\mathrm{a}}$ \\
\hline $7-8 \mathrm{wks}$ & $350 \pm 19 \mathrm{a}^{\mathrm{b}}$ & $368.8 \pm 25^{\mathrm{ab}}$ & $410 \pm 30.1^{\mathrm{a}}$ & $356.3 \pm 24^{\mathrm{ab}}$ \\
\hline $8-9 \mathrm{wks}$ & $306.3 \pm 24^{\mathrm{a}}$ & $281.3 \pm 18.7^{\mathrm{b}}$ & $288.8 \pm 16.3^{\mathrm{ab}}$ & $301.3 \pm 22.7^{\mathrm{a}}$ \\
\hline $9-10 \mathrm{wks}$ & $266.3 \pm 27.2^{\mathrm{ab}}$ & $250 \pm 20^{\mathrm{b}}$ & $303.8 \pm 27^{\mathrm{a}}$ & $297.5 \pm 20.5^{\mathrm{a}}$ \\
\hline Total $(2-10)$ & $2945.2 \pm 22.3^{\mathrm{b}}$ & $3084.2 \pm 30.3^{\mathrm{ab}}$ & $3141.5 \pm 30.8^{\mathrm{a}}$ & $3169 \pm 29.1^{\mathrm{a}}$ \\
\hline
\end{tabular}

a Significant difference when compared with control when $(\mathrm{P}<0.05)$

${ }^{b}$ Significant difference when compared with other treated groups when $(\mathrm{P}<0.05)$

Table 5: Feed consumption (g/chick) of ducks fed the different experimental diets.

\begin{tabular}{ccccc}
\hline Age/group & 1 & 2 & 3 & 4 \\
\hline 2-3 wks & $700.9 \pm 19.7$ & $550.3 \pm 15.5$ & $615.8 \pm 22.4$ & $610.5 \pm 23.9$ \\
$3-4 \mathrm{wks}$ & $1020 \pm 21.6$ & $1130 \pm 28.1$ & $1040 \pm 20.00$ & $1010 \pm 21.5$ \\
$4-5 \mathrm{wks}$ & $1143 \pm 35.3$ & $1100 \pm 34.1$ & $1140 \pm 33.1$ & $1100.7 \pm 23.4$ \\
$5-6 \mathrm{wks}$ & $1250 \pm 51.9$ & $1299 \pm 67.5$ & $1207 \pm 56.31$ & $1210 \pm 34.9$ \\
6-7 wks & $1400 \pm 89.2$ & $1355 \pm 80.3$ & $1300 \pm 78.5$ & $1390 \pm 46.8$ \\
$7-8 \mathrm{wks}$ & $1418 \pm 92.5$ & $1440 \pm 90.7$ & $1453 \pm 86.5$ & $1490 \pm 67.2$ \\
$8-9 \mathrm{wks}$ & $1500 \pm 100.6$ & $1500 \pm 101.2$ & $1530 \pm 98.9$ & $1500 \pm 73.9$ \\
$9-10 \mathrm{wks}$ & $1580 \pm 120$ & $1582 \pm 110.4$ & $1600 \pm 117.8$ & 1553.80 .2 \\
& & & & 9864.2 \\
\hline
\end{tabular}


Table 6: Feed conversion index for ducks fed the different experimental diets.

\begin{tabular}{ccccc}
\hline Age/group & $\mathbf{1}$ & $\mathbf{2}$ & $\mathbf{3}$ & $\mathbf{4}$ \\
\hline $2-3$ wks & $1.56 \pm 0.06^{\mathrm{ab}}$ & $1.38 \pm 0.04^{\mathrm{ab}}$ & $1.72 \pm 0.05^{\mathrm{a}}$ & $1.28 \pm 0.05^{\mathrm{b}}$ \\
\hline $3-4 \mathrm{wks}$ & $2.46 \pm 0.11 \mathrm{a}^{\mathrm{b}}$ & $3.62 \pm 0.07^{\mathrm{a}}$ & $2.5 \pm 0.16^{\mathrm{b}}$ & $2.64 \pm 0.17^{\mathrm{ab}}$ \\
\hline $4-5 \mathrm{wks}$ & $3.44 \pm 0.22^{\mathrm{a}}$ & $2.81 \pm 0.13^{\mathrm{b}}$ & $3.42 \pm 0.24^{\mathrm{ab}}$ & $3.14 \pm 0.13^{\mathrm{ab}}$ \\
\hline $5-6 \mathrm{wks}$ & $3.41 \pm 0.30^{\mathrm{a}}$ & $2.81 \pm 0.20^{\mathrm{ab}}$ & $2.61 \pm 0.16^{\mathrm{b}}$ & $2.53 \pm 0.15^{\mathrm{ab}}$ \\
\hline $6-7 \mathrm{wks}$ & $3.5 \pm 0.27^{\mathrm{a}}$ & $2.85 \pm 0.17^{\mathrm{b}}$ & $3.41 \pm 0.23^{\mathrm{ab}}$ & $2.86 \pm 0.14^{\mathrm{ab}}$ \\
\hline $7-8 \mathrm{wks}$ & $4.13 \pm 0.22^{\mathrm{ab}}$ & $4.0 \pm 0.25^{\mathrm{ab}}$ & $3.68 \pm 0.29^{\mathrm{b}}$ & $4.29 \pm 0.24^{\mathrm{a}}$ \\
\hline $8-9 \mathrm{wks}$ & $5.12 \pm 0.42$ & $5.53 \pm 0.43$ & $5.41 \pm 0.31$ & $5.19 \pm 0.42$ \\
\hline $9-10 \mathrm{wks}$ & $6.38 \pm 0.56^{\mathrm{a}}$ & $6.56 \pm 0.44^{\mathrm{a}}$ & $5.48 \pm 0.50^{\mathrm{b}}$ & $5.82 \pm 0.50^{\mathrm{ab}}$ \\
\hline Total $(2-10)$ & $3.39 \pm 0.34^{\mathrm{a}}$ & $3.22 \pm 0.45^{\mathrm{ab}}$ & $3.14 \pm 0.17^{\mathrm{ab}}$ & $3.11 \pm 0.06^{\mathrm{b}}$ \\
\hline
\end{tabular}

Carcass traits including dressed carcass weights, dressing percentages, percentages of some internal organs of ducks are revealed in Table 7. The effect of leftover food addition to duck diets on serum biochemical parameters including total protein, globulin, albumin, cholesterol and triglycerides are tabulated in Table 8 . Table 9 revealed economical evaluation of duck performance in the different experimental groups.

Table 7: Carcass traits of ducks as influenced by the different experimental diets.

\begin{tabular}{ccccc}
\hline Parameter/group & 1 & 2 & 3 & 4 \\
\hline Pre-slaughter wt. & $3133 \pm 218.6^{\mathrm{ab}}$ & $3133 \pm 66.7^{\mathrm{ab}}$ & $3317 \pm 148^{\mathrm{b}}$ & $3450 \pm 160.7^{\mathrm{a}}$ \\
\hline Hot carcass weight $(\mathrm{g})$ & $2704 \pm 239^{\mathrm{b}}$ & $2725 \pm 89.5^{\mathrm{ab}}$ & $2907 \pm 150^{\mathrm{a}}$ & $2920 \pm 130^{\mathrm{a}}$ \\
\hline Dressed weight $(\mathrm{g})$ & $2379 \pm 220^{\mathrm{b}}$ & $2389 \pm 89.5^{\mathrm{ab}}$ & $2619 \pm 116^{\mathrm{a}}$ & $2631 \pm 137.5^{\mathrm{a}}$ \\
\hline Dressing (\%) & $75.6 \pm 2.0$ & $77.2 \pm 0.46$ & $76.5 \pm 0.54$ & $79.3 \pm 0.59$ \\
\hline Gizzard \% & $3.38 \pm 0.12$ & $3.14 \pm 0.06$ & $3.37 \pm 0.10$ & $3.45 \pm 0.10$ \\
\hline Liver \% & $1.78 \pm 0.09^{\mathrm{a}}$ & $1.57 \pm 0.17^{\mathrm{b}}$ & $1.57 \pm 0.17^{\mathrm{b}}$ & $1.78 \pm 0.07^{\mathrm{a}}$ \\
\hline Heart \% & $0.65 \pm 0.14$ & $0.70 \pm 0.04$ & $0.69 \pm 0.08$ & $0.74 \pm 0.03$ \\
\hline Spleen\% & $0.10 \pm 0.14$ & $0.07 \pm 0.01$ & $0.06 \pm 0.01$ & $0.10 \pm 0.01$ \\
\hline
\end{tabular}

a Significant difference when compared with control when $(\mathrm{P}<0.05)$

${ }^{b}$ Significant difference when compared with other treated groups when $(\mathrm{P}<0.05)$

Table 8: Serum biochemical parameters of ducks fed the different experimental diets.

\begin{tabular}{ccccc}
\hline Parameters/group & 1 & 2 & 3 & 4 \\
\hline Total protein $(\mathrm{g} / \mathrm{dl})$ & $4.4 \pm 0.57^{\mathrm{a}}$ & $2.93 \pm 0.23^{\mathrm{ab}}$ & $2.73 \pm 0.06^{\mathrm{ab}}$ & $3.7 \pm 1.0^{\mathrm{b}}$ \\
\hline Albumin $(\mathrm{g} / \mathrm{dl})$ & $1.43 \pm 0.08$ & $1.33 \pm 0.12$ & $1.23 \pm 0.06$ & $1.63 \pm 0.06$ \\
\hline Globulin $(\mathrm{g} / \mathrm{dl})$ & $3.0 \pm 0.66^{\mathrm{a}}$ & $1.6 \pm 0.11^{\mathrm{ab}}$ & $1.5 \pm 0.0^{\mathrm{ab}}$ & $2.06 \pm 0.08^{\mathrm{b}}$ \\
\hline Cholesterol $(\mathrm{mg} / \mathrm{dl})$ & $144.3 \pm 5.8^{\mathrm{a}}$ & $136.7 \pm 12.8^{\mathrm{ab}}$ & $130.7 \pm 24.2^{\mathrm{b}}$ & $155 \pm 11.5^{\mathrm{a}}$ \\
\hline Triglycerides $(\mathrm{mg} / \mathrm{dl})$ & $36.0 \pm 13.0^{\mathrm{b}}$ & $51.6 \pm 0.88^{\mathrm{ab}}$ & $65.0 \pm 13.8^{\mathrm{ab}}$ & $78.3 \pm 17.5^{\mathrm{a}}$ \\
\hline
\end{tabular}

a Significant difference when compared with control when $(\mathrm{P}<0.05)$

b Significant difference when compared with other treated groups when $(\mathrm{P}<0.05)$

Table 9: Economical evaluation of ducks fed the different experimental diets.

\begin{tabular}{ccccc}
\hline Item/group & 1 & 2 & 3 & 4 \\
\hline Average feed intake kg/bird & 10.06 & 10.46 & 10.53 & 10.73 \\
\hline Price/kg feed (L.E) & 5.83 & 5.36 & 4.64 & 4.00 \\
\hline Total feed cost (L.E) & 58.64 & 56.10 & 48.85 & 42.92 \\
\hline Totalproduction cost (L.E) & 80.64 & 78.10 & 70.85 & 64.92 \\
\hline Body weight (kg/bird) & 3.340 & 3.500 & 3.533 & 3.539 \\
\hline Price/kg body weight (L.E) & 30.00 & 30.00 & 30.00 & 30.00 \\
\hline Net revenue (L.E) & 19.56 & 26.90 & 35.14 & 41.25 \\
\hline Economic feed efficiency (\%) & 24.25 & 34.44 & 49.59 & 63.53 \\
\hline Relative economic feed efficiency & 100.00 & 142.02 & 204.49 & 261.97 \\
\hline
\end{tabular}




\section{DISCUSSION}

\section{Growth performance:}

There were significant differences $(p<0.05)$ in the weekly body weight development and weekly weight gain between the different experimental groups as shown in Tables $3 \& 4$. At the end of the experiment, leftover food supplemented groups (groups 2, 3\&4) recorded higher body weight $(3500 \pm 37.8,3533 \pm 45.8$ and $3539 \pm 52.3 \mathrm{~g}$, respectively) than that recorded by control group $(3340 \pm 40.8 \mathrm{~g})$. The highest body weight gain was recorded in the fourth group $(3169 \pm 29.1 \mathrm{~g})$ while the lowest value was recorded in the control group $(2945.2 \pm 22.3 \mathrm{~g})$. These results agreed with that reported by Chen et al. (2007) who found that addition of $5 \%$ dehydrated food waste product to broiler diets increased body weight gains during the 4 to 8 weeks of age. Farhat et al. (2001) revealed that, ducks fed on partial food wastes had significantly $(\mathrm{p}<0.05)$ higher growth performance including body weight gain. In contrast Cho et al. (2004) found that body weight gain was slightly higher in control group than dried leftover food supplemented groups. Concerning the feed intake, addition of dried leftover food to duck diets had no significant effect. For the whole experimental period, groups fed on diets containing 10, 20, and 30\% leftover food consumed numerically less feed $(9956,9886,9864 \mathrm{~g} / \mathrm{bird})$ than control $(10011 \mathrm{~g} / \mathrm{bird})$. These results are supported by the findings of Farhat et al. (2001) who found that addition of food waste to Muscovy duck diets decrease feed intake. On the contrary, Cho et al. (2004) found that average daily feed intake of group fed diets containing $20 \%$ dried leftover food was significantly higher than control $(p<0.05)$. Inclusion of leftover food to duck diets had no significant effect on the feed conversion ratio. The best feed conversion ratio was recorded by the fourth group fed on diet containing 30\% leftover food (3.11) in comparison with control (3.39) Cho et al. (2004) revealed that feed conversion ratio of broilers fed on diets containing leftover food was higher than that recorded in control group. Chen et al. (2007) found that feed conversion ratio linearly increased with increasing the level of food waste inclusion. This may be due to the ability of duck gastrointestinal tract to digest the relatively high fiber content of the leftover food (Chen et al., 2007). Also, the increase in digestibility may be due to the proportion of saturated fatty acids to the unsaturated one (Farahat et al., 1998).

\section{Carcass traits:}

The inclusion of leftover food to the duck diets did not affect significantly the dressing percentages, carcass weights and relative weights of gizzard, heart and spleen. Similar results were obtained by Chen et al. (2007) who reported that diets contain dried leftover food had no significant effect $(\mathrm{p}<0.05)$ on the dressing percentage, carcass weight and relative weights of the liver, heart. In this respect, Cho et al. (2004) found that the proportion of crop, heart, liver and gizzard to body weight was increased with increasing the level of dried leftover food in the diet.

\section{Serum biochemical parameters:}

Serum biochemical values revealed significant differences $(p<0.05)$ among the experimental groups by adding leftover food to the diets. Total serum protein were decreased in groups containing 10, 20 and $30 \%$ leftover food respectively $(2.93,2.73$, $3.70 \mathrm{~g} / \mathrm{dl}$ ) compared with control (4.4). Concerning serum cholesterol content, addition of leftover food to duck diets had no significant effect $(\mathrm{p}<0.05)$ on serum cholesterol value and ducks fed diet containing $30 \%$ leftover food recorded the highest serum cholesterol value $(155 \mathrm{mg} / \mathrm{dl})$ when compared with control $(144 \mathrm{mg} / \mathrm{dl})$. According to the previous researches, one of the factors affecting content of cholesterol in the blood was fiber content in the feed. Balmer and Zilversmit (1974) suggested that cellulose as an indigestible material controlled the cholesterol metabolism and affected concentration of cholesterol in blood and cholesterol turnover rate. Results in Table 7 revealed that cholesterol content of birds fed on diet had $30 \%$ leftover food was higher than other treated groups and control. The results showed significant increase of triglycerides content of all treated groups. Group 4 fed diet containing 30\% leftover food had the highest value $(78.3 \pm 17.5 \mathrm{mgdl})$, followed by third group $(65.0 \pm 13.8 \mathrm{mg} / \mathrm{dl})$ and the lowest value was recorded in control group $(36 \pm 13.0$ $\mathrm{mg} / \mathrm{dl})$.

\section{Economical evaluation:}

The influence of the different dietary treatments on economic feed efficiency (EFE) and relative economic efficiency (REE) was measured by feed cost / kg live body weight relative to control group of ducks. The economical evaluation of ducks including total feed cost, total production cost, net revenue, economical feed efficiency, and relative economic efficiency in different dietary treatments are summarized in Table 9. The total feed cost was lowest (42.92 LE) in group 4 fed on diet containing $30 \%$ leftover food and the highest $(58.64 \mathrm{LE})$ in the control group. Net revenue, economical feed efficiency and relative economical feed efficiency were higher in all treated groups than that recorded by control one. The highest economical feed efficiency was recorded in birds of the fourth group fed on diet had $30 \%$ leftover food $(63.53 \%)$ followed by birds in the third group (49.59\%) while the worst value was recorded in control group $(24.25 \%)$. The data of the economical evaluation in ducks revealed that adding different levels of leftover food improved economic feed efficiency. Priority of economical feed efficiency in the fourth groupfed diet containing 30\% leftover 
food may be due to better feed and energy utilization and conversion. Similar result was reported by Cho et al. (2004) who found that feed cost per unit $\mathrm{kg}$ was decreased with increasing the level of dried leftover food in diet and recommended that in viewpoint of economies, dried leftover food could be included at least more than $10 \%$ in broiler diet for the starter period and up to $30 \%$ in broiler chicks diet for the finisher period.

Results of the current study concluded that the best growth performance and economical feed efficiency was observed in ducks fed on diet containing $30 \%$ leftover feed which surpassing all treated groups and achieved the best body weight gain.

\section{REFERENCES}

AOAC (Assocition of Official Analytical Chemists) (1990): Official Methods of Analysis(14 ${ }^{\text {th }} \mathrm{Ed}$.), Washington, DC.

Balmer, J. and Zilversmit, D.B. (1974): Effects of dietary roughage on cholesterol absorption, cholesterol turnover and steroid excretion in the rat. J. Nutr. 104: 1319-1328.

Chen, K.L.; Chang, H.J.; Yang, C.K.; You, S.H.; Jenq, H.D. and B, Y. (2007): Effect of dietary inclusion of dehydrated food waste products on Taiwan native chicken. Asian-Aust. J. Anim. Sci; 20(5).754-760.

Cho, Y.M.; Lee, G.W.; Jang, J.S.; Shin, I.S.; Myung, I.H.; Choi, K.S.; Bai, I.H. and Yang, C.J. (2004): Effects of feeding dried leftover food on growth and body composition of broiler chicks. Asian-Aus. J. Anim. Sci. 17(3): 386393.

Cho, Y.M. Shin, I.S. and Yang, C.J. (2004): Effects of feeding dried leftover food on productivity of laying hens. Asian-Aust. J. Anim. Sci 17(4): 518-522.
Farhat, A.; Normand, L.; Chavez, E.R. and Touchburn, S.P. (2001): Comparison of growth performance, carcass yield and composition, and fatty acid profiles of Pekin and Muscovy ducklings fed diets based on food wastes. Can. J. Anim. Sci. 81: 107-114.

Farhat, A.; Normand, L.; Chavez, E.R. and Touchburn, S.P. (1998): Nutrient digestibility in food waste ingredients for Pekin and Muscovy ducks. J. Poult. Sci. 77: 1371-1376.

IAEA (2011): Animal Production and Health Newsletter, Joint FAO/International Atomic Energy Agency Programme. 54. 35.

Kim, C.H.; Song, Y.H.; Chae, B.J. and Rhee, Y.C. (2001): Effects of feeding extruded swine manure and food waste mixture diets on growth performance, body composition and feeding behavior of broilers. J. Anim. Sci. Technol. Kor.43(1): 91-100.

Kim, N.C. (1965): Feedstuff of food garbage by the rapid steam drying. J. KOWREC. Kor. 3(2): 69-78.

Kornegay, E.T.; Vander Noot, G.W.; Barth, K.M.; MacGrath, W.S.; Welch, J.G. and Purkhiser, E.D. (1965): Nutritive value of garbage as a feed for swine. I. Chemicals composition, digestibility and nitrogen utilization of various types of garbage. J. Anim. Sci. 24: 319-324.

NRC (1994): Nutrients requirements of poultry, $8^{\text {th }}$ ed. National Acad. Press, Washington, DC.

Price, A.T.; Derr, D.A.; Sulir, J.L. and Higgins, A.J. (1985): Food waste recycling through swine. Biocycle J. Waste Recyc. 26: 34-37.

SAS (1995): SAS Users Guide Statistics. Statistical Analysis System.Inst.

Yang, S.Y.; Park, H.Y.; Kim. C.W and Park, K.K. (2001): Isolation of halo-tolerant lactic acid bacteria for fermentation of food wastes. J. L. H. Kor. 7(2): 137-140. 


\title{
استخدام بقايا الطعام المجفف كمواد علف غير تقليدية في علائق البط المسكوفي \\ إيناس عسر فكري موسى ، حسن عباس محد عبل الرحيم ، جيهان رجب محد داوود
}

E-mail: drenas_86@yahoo.com_Assiut University web-site: www.aun.edu.eg

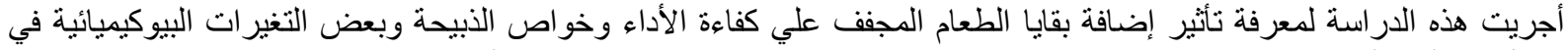

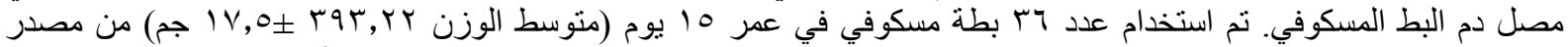

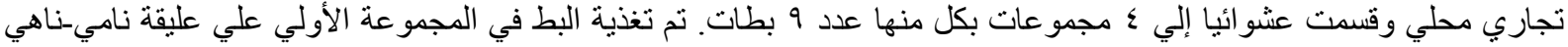

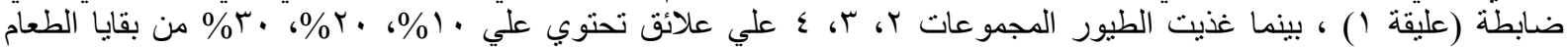

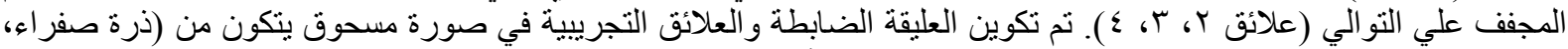

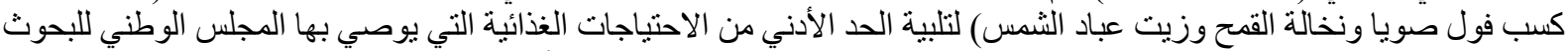

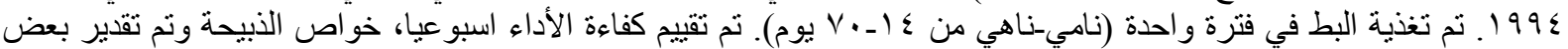

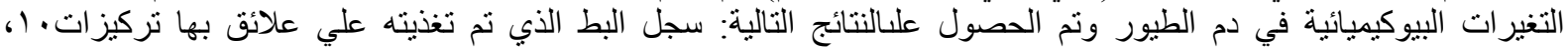

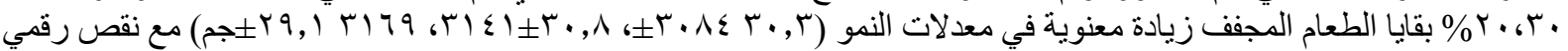

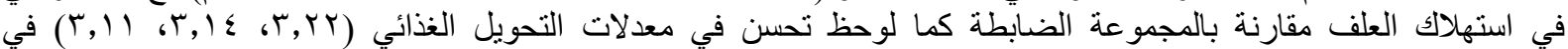

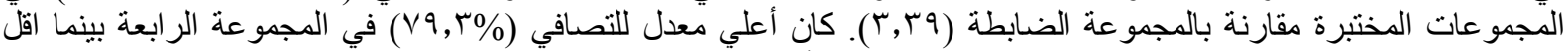

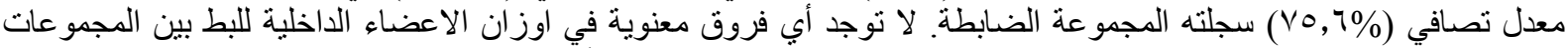

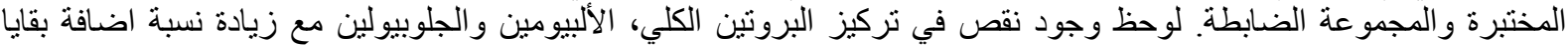

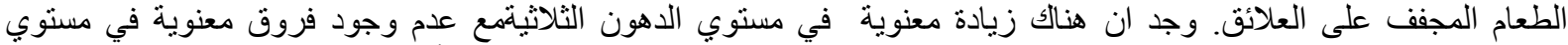

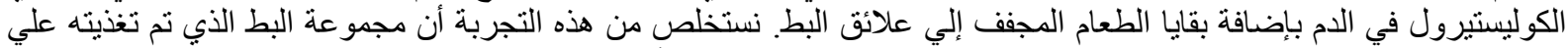

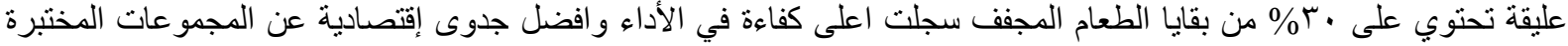
الاخرى حيث سجلت طيور هذه المجمو عة اعلى معدل زيادة في وزن الجسم.
\end{abstract}

